GLedhill, A. W. (1956). J. gen. Microbiol. 15, 292-304

\title{
Quantitative Aspects of the Enhancing Action of Epery- throzoa on the Pathogenicity of Mouse Hepatitis Virus
}

\author{
By A. W. GLEDHILL \\ National Institute for Medical Research, Mill Hill, London, N.W. 7
}

SUMMARY: The enhanced pathogenicity of mouse hepatitis virus (MHV 1) in mice infected with Eperythrozöon coccoides is shown to result from the increased probability of virus particles actively infecting cells in the presence of the blood parasite. The ratio $(\alpha)$ of the probability that a virus particle will infect a cell in the absence of $\boldsymbol{E}$. coccoides to the probability of its doing so in the presence of $\boldsymbol{E}$. coccoides has been estimated by two independent methods. One method depends upon the increased infectivity of dilute suspensions of MHV 1 for mice pretreated with $E$. coccoides and gives values for $\alpha$ varying between $0 \cdot 34$ and $0 \cdot 77$, with a mean of $0 \cdot 5$. The other method, in which relatively large doses of MHV 1 are used, depends upon estimating the slope of the regression line of suryival time on time of infection with $E$. coccoides, and yields a value for $\alpha$ of 0.49 , with 0.95 probability limits of 0.37 and 0.61 . The enhancing effect of $E$. coccoides on the pathogenicity of MHV 1 is attributed to the parasite increasing the ratio of active to latent infections of cells by the virus.

Mouse hepatitis virus (MHV 1) produces a mild, rarely fatal, hepatitis in weanling VS mice but when such mice are simultaneously infected with Eperythrozöon coccoides (a normally harmless blood parasite of mice) fatal hepatitis is invariably produced (Gledhill, Dick \& Andrewes, 1952; Niven, Dick, Gledhill \& Andrewes, 1952; Gledhill, Dick \& Niven, 1955). When mice are first infected with virus and then inoculated a day or so later with a mixture of virus and $E$. coccoides, the majority survive. This decreased mortality which is produced by a prior inoculation of MHV 1 cannot be ascribed to humoral antibody (Gledhill \& Dick, 1955; Dick, Gledhill \& Niven, to be published). To explain this observation and observations relating to mice which are virus carriers, Gledhill \& Dick (1955) advanced the hypothesis that when MHV 1 suspension is introduced intraperitoneally into weanling mice, the virus produces active infections of some liver cells and latent infections of other liver cells. By active infections of cells are meant infections in which cells liberate virus and are probably destroyed; and by latent infections are meant infections in which the cells do not forthwith liberate virus but become resistant to subsequent infection. It was suggested that prior or concomitant infection with $E$. coccoides enables active rather than latent infections of cells to be produced and thereby gives rise to fatal hepatitis. The mild regressive disease produced by MHV 1 in the absence of $E$. coccoides is due to latent infections of many eells.

In this paper it is shown that when mice are inoculated with small doses of Eperythrozöon coccoides more mice develop hepatitis when they have been preinoculated with $E$. coccoides than when they are simultaneously infected with virus and blood parasite, and that the survival time of mice is greatly 
decreased by previous inoculation with $E$. coccoides. The relationship between survival time and time of inoculation with E. coccoides was found to be linear for constant doses of virus and blood parasite. All the results may be explained by the hypothesis that in the absence of $E$. coccoides, MHV 1 produces active and latent infections in about equal proportions of liver cells, while in the presence of $E$. coccoides the virus produces only active infections of liver cells.

In order to make the purpose and methods of this paper more readily understood it is useful to recall that when a high dilution of Eperythrozöon coccoides is inoculated into mice, the parasites become abundant in the blood on about the 4th day and, rising to a maximum on about the 6 th day, they decline more

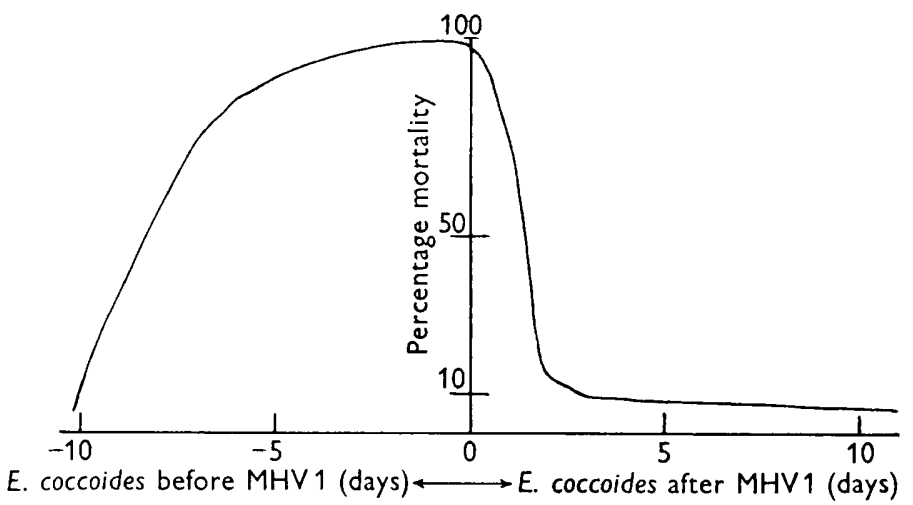

Fig. 1. Mortality for different relative times of inoculating Eperythrozöon coccoides and MHV 1.

slowly, becoming very scarce in blood smears after about the 10th day. When E. coccoides is inoculated into mice on the same day as virus, fatal hepatitis results. When mice are inoculated with $E$. coccoides more than one day after inoculation with virus, many survive as a result of the development of cellular resistance to the virus. When the inoculation of $\boldsymbol{E}$. coccoides precedes that of virus by 1-5 days the mortality remains at almost $100 \%$ and declines to about $75 \%$ and $10 \%$ when the blood parasite precedes the virus by 7 and 10 days, respectively. This sharp decline in mortality when the inoculation of $E$. coccoides precedes that of virus by more than 7 days is believed to be due to the low concentration of the blood parasite in the mouse tissues during the later phase of virus growth. The mortality curve for different times of inoculation with $E$. coccoides, based on published and unpublished records, is shown in Fig. 1.

\section{METHODS}

The general methods have been described elsewhere (Gledhill \& Andrewes, 1951; Gledhill et al. 1952, 1955). Weanling VS mice aged 20-22 days were employed in all experiments. Mice of this strain originated from the virussusceptible, bacteria-susceptible variant of the Rockefeller strain of albino mice (Webster, 1937) and have been bred since 1949 at the National Institute for Medical Research, Mill Hill. Samples of two pools (pools 1 and 2 ) of $10 \%$ MHV 1 infected mouse liver spleen suspension which were stored at $-\mathbf{7 0}^{\circ}$ 
were used. These pools were titrated intraperitoneally in mice which had been infected 2 days previously with Eperythrozöon coccoides. The ID 50 was $0.2 \times 10^{-4.5} \mathrm{ml}$. for pool 1 virus and $0.2 \times 10^{-3.8} \mathrm{ml}$. for pool 2 virus as calculated by the method of Reed \& Muench (1938) from the proportion of mice with fatal or severe hepatitis at autopsy 7 days after injection of replicate four-fold or less dilutions of virus into groups of 6-10 mice. Experiments to be described yield regression lines (see Fig. 2) from which the ID 50's can be estimated as $\mathbf{0 . 2} \times$ $10^{-4.8} \mathrm{ml}$. for pool 1 and $0.2 \times 10^{-3.8}$ for pool 2 (see foot of Table 2). Suspensions of $E$. coccoides at dilutions of $10^{-7}$ were used to infect mice. This dilution was used to exclude the possibility that MHV 1 might occasionally be present in the inoculum as a result of its liberation by $\boldsymbol{E}$. coccoides in sporadic carriers amongst the mice which provided the suspension of this parasite (Gledhill \& Dick, 1955).

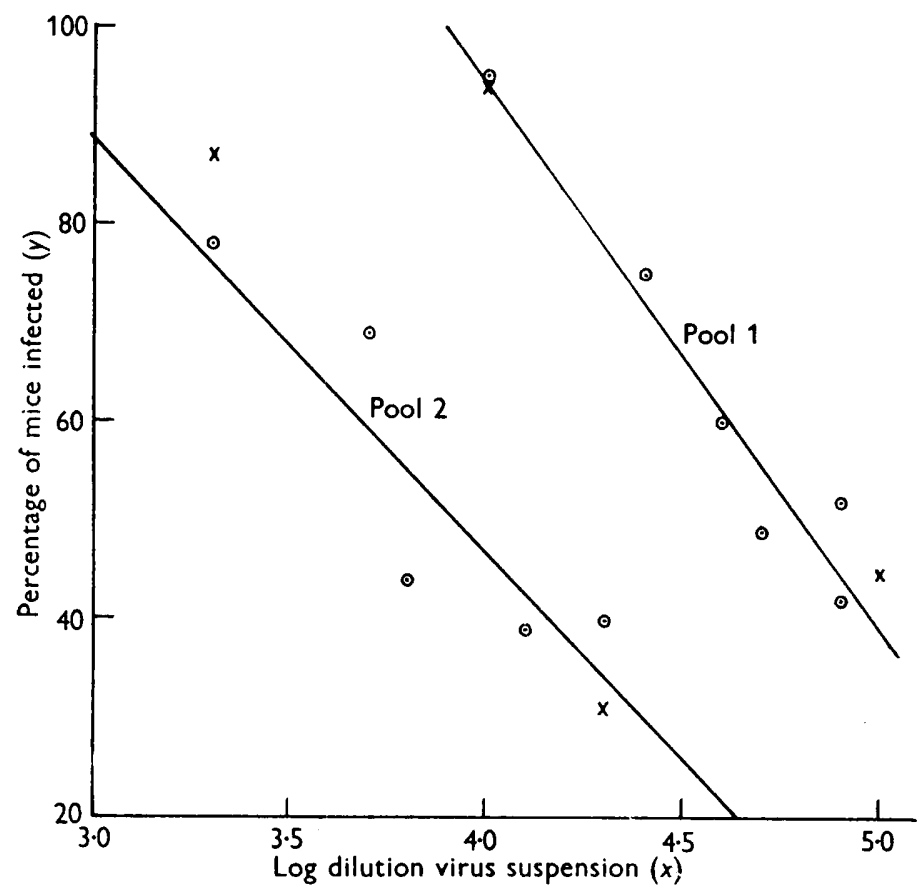

Fig. 2. Regression of percentage mice infected $(y)$ on $\log$ dilution $(x)$. $\odot$, points used for determining regression lines (see Table 2); $\times$, independent points from confirmatory experiments. Regression lines calculated from $\odot$ points: Pool 1 virus $-Y=317-$ $55 \cdot 6 x$; Pool 2 virus- $Y=216-42 \cdot 2 x$.

\section{RESULTS}

Increased infectivity of dilute $M H V$ suspensions in the effective presence of Eperythrozöon coccoides

The hypothesis that infection with Eperythrozöon coccoides enables MHV 1 virus to produce active rather than latent infections of cells suggested that if a minimal dose of virus were inoculated the proportion of mice infected would be 
increased by the presence of $E$. coccoides in effective concentration at the time of inoculation of virus. For, under these conditions, cells are actively infected, whereas in the absence of $\boldsymbol{E}$. coccoides some infections of cells are latent and these would not initiate progressive hepatitis. The increased infectivity due to $E$. coccoides results only from its effective presence at the time of infection with MHV 1 and during the first cycle of virus growth. In contrast, the increased severity of MHV 1 hepatitis in mice infected with $E$. coccoides results mainly from the effective presence of the parasite during the middle and late cycles of virus growth, when infection is spreading to the majority of liver cells. In mice inoculated with $E$. coccoides suspension diluted to $10^{-4}$, the parasite is not abundant in the blood for 4 or 5 days. Moreover, the experiment detailed later (pp. 299-302) and other experiments show that $E$. coccoides does not enhance the growth of MHV 1 virus until the parasite has become abundant in the blood. Thus we may use the expression 'the effective presence of $E$. coccoides' to mean its presence in sufficient concentration to enhance the growth of virus. It was considered that if a high dilution of $E$. coccoides were inoculated simultaneously with virus or preceded the virus by 2 days, $E$. coccoides would not be effectively present during the first cycle of virus multiplication and so would not increase the infectivity of the virus suspension. Experiments were devised to compare the infectivity of a suitable dose of MHV 1 virus in mice infected with $\boldsymbol{E}$. coccoides 5-7 days before inoculating them with virus (termed ' mice preinfected with $E$. coccoides') and in mice infected simultaneously or not more than 2 days previously with $E$. coccoides (cermed 'mice simultaneously infected with $E$. coccoides)'. Doses of virus were chosen which would infect only a proportion of the inoculated mice, and the results were determined by the specific deaths and by the lesions shown by the remainder at autopsy 7 days after infection with virus. Since all mice had been inoculated with E. coccoides, infected mice of both groups developed severe hepatitis with gross lesions and were readily distinguishable from mice which failed to develop active infection with virus. Experiments were concluded by sacrificing survivors on the 7 th day after virus inoculation rather than by basing results on the specific mortalities within a somewhat longer time because in mice treated with $E$. coccoides 7 or even 5 days before virus, severe hepatitis does not invariably end fatally, as already noted (see Fig. 1). Such experiments yielded estimates of the increased infectivity of virus in mice pretreated with $E$. coccoides.

Two independent experiments were carried out with virus of each pool and the results are shown in Table 1 . In each experiment the infectivity of virus suspension was higher for mice pretreated with Eperythrozöon coccoides by amounts varying from 6 to $26 \%$. Two of the differences are statistically significant and the difference of the sum of the experiments is highly significant. Before concluding that virus suspension has increased infectivity for mice pre-treated with $E$. coccoides, another possible explanation of the observed differences must be considered. It should be recalled that infection with E. coccoides liberates MHV 1 in about $10 \%$ of VS mice and that the liberated virus produces hepatitis in them (Gledhill \& Dick, 1955). It is therefore possible that the observed differences might be due to spontaneous MHV I 
hepatitis having become observable in a higher proportion of mice which had been infected with $\boldsymbol{E}$. coccoides 5-7 days before giving the virus, as compared with mice simultaneously infected with $E$. coccoides + virus. This was investigated in the following experiment in which the proportions of mice with hepatitis at autopsy 7 and 12 days after infection with $E$. coccoides were compared. Fifty of 100 mice were inoculated with $E$. coccoides, and 5 days later the other 50 were similarly inoculated. All the mice were autopsied after a further 7 days and in each group of 50 there were 4 with hepatitis such that they would have

Table 1. Higher infectivity of dilute virus MHV 1 suspension for mice pre-treated with Eperythrozöon coccoides

\begin{tabular}{|c|c|c|c|c|c|c|c|c|}
\hline \multirow{3}{*}{$\begin{array}{c}\text { Expt. } \\
\text { no. }\end{array}$} & \multirow[b]{3}{*}{ Virus pool } & \multirow{3}{*}{$\begin{array}{c}-\log \\
\text { dose }\end{array}$} & \multicolumn{6}{|c|}{ Infectivity ratio, mice infected/total mice } \\
\hline & & & \multirow{2}{*}{$\begin{array}{l}\text { Pre-treated } \\
\text { with } \\
\text { E. coccoides }\end{array}$} & \multirow{2}{*}{$\begin{array}{c}\text { Simultaneously- } \\
\text { treated with } \\
\text { E. coccoides }\end{array}$} & \multicolumn{3}{|c|}{$\begin{array}{c}\text { Probability of } \\
\text { difference occurring } \\
\text { by chance }\end{array}$} & \multirow{2}{*}{$\begin{array}{c}\text { Percentage } \\
\text { difference } \\
(\%)\end{array}$} \\
\hline & & & & & $\chi^{2}$ & $n=1$ & $\boldsymbol{P}$ & \\
\hline 1 & P $1(\log$ ID 504.8$)$ & $4 \cdot 7$ & $46 / 68(68 \%)$ & $33 / 68(49 \%)$ & $4 \cdot 35$ & & $<0.05$ & 19 \\
\hline 2 & P1 $(\log$ ID 504.8$)$ & $5 \cdot 0$ & $31 / 61(51 \%)$ & $33 / 73(45 \%)$ & $0 \cdot 22$ & & $>0.5$ & 6 \\
\hline 3 & P2 (log ID 503.9$)$ & $4 \cdot 1$ & $44 / 81(54 \%)$ & $35 / 89(39 \%)$ & $3 \cdot 25$ & & $>0.05$ & 15 \\
\hline \multirow[t]{2}{*}{4} & P2 (log ID $503 \cdot 9)$ & $4 \cdot 3$ & $26 / 46(57 \%)$ & $18 / 58(31 \%)$ & $5 \cdot 82$ & & $<0.02$ & 26 \\
\hline & & Total & $147 / 256(57 \cdot 4 \%)$ & $119 / 288(41 \cdot 3 \%)$ & $13 \cdot 43$ & & $<0.001$ & 16 \\
\hline
\end{tabular}

been falsely accepted as infected in titrations of virus. This single experiment would suggest that carriers of MHV 1 virus influence the two methods of titration to an equal extent. Moreover, even supposing that $10 \%$ of mice developed hepatitis 12 days after infection with $\boldsymbol{E}$. coccoides and no mice developed it within 7 days, an allowance for this hypothetical situation can be made in figures presented in Table 1 . When this is done the infectivity ratio in mice pretreated with $E$. coccoides becomes $135 / 256$ instead of $147 / 256$, and, the ratio for mice not pretreated with $E$. coccoides remaining $119 / 288$, the difference becomes $11 \%$ instead of $16 \%$. The probability of this difference occurring by chance is $0 \cdot 01\left(\chi^{2}=6 \cdot 64\right)$. It may therefore be concluded that the difference between the two methods of titration is a real one and is attributable to the increased infectivity of virus suspension for mice pre-treated with $E$. coccoides.

The difference between the proportion of mice demonstrably infected following inoculation of the same number of virus particles into simultaneouslytreated and pretreated mice was determined. This enabled an estimate to be made of the greater number of virus particles needed to produce the same increase in the proportion of mice infected. This was done by infecting with dilutions of virus mice which had been inoculated with Eperythrozöon coccoides within 2 days and determining the proportion which developed hepatitis, as in previous experiments. These determinations (Table 2 ) represent the decreasing percentage of infected mice with increase of log dilution of virus suspension and are shown graphically in Fig. 2, together with the regression lines of percentage of mice infected on log dilution of virus calculated from them. It will be seen that the observations tend to be distributed linearly and that the 
regression lines for the two pools are nearly parallel. The slopes of the lines, viz. $55 \cdot 6$ and $42 \cdot 2$ respectively, represents the increase in percentage infected per unit $\log$ dilution. The percentage higher infectivities of pool 1 and pool 2 virus for pre-treated mice were 19 and $15 \%$ respectively (Table 1, Expts. 1 and $3)$. To get $19 \%$ increased infectivity with pool 1 virus would require a decrease of $\log$ dilution of $19 / 55 \cdot 6$ or $0 \cdot 34$, and to get $15 \%$ increased infectivity with pool 2 virus would require a decrease of $\log$ dilution of $15 / 42 \cdot 2$ or $0 \cdot 36$.

Table 2. Regression of infectivity for mice simultaneously treated with Eperythrozöon coccoides on log dilution of virus

\begin{tabular}{|c|c|c|c|c|c|}
\hline \multirow[b]{3}{*}{$\begin{array}{c}\text { Log dilution } \\
\text { of virus } \\
(x)\end{array}$} & \multicolumn{2}{|l|}{ Pool 1 virus } & \multicolumn{3}{|c|}{ Pool 2 virus } \\
\hline & \multicolumn{2}{|c|}{ Infectivity ratio } & \multirow[b]{2}{*}{$\begin{array}{l}\text { Log dilution } \\
\text { of virus } \\
(x)\end{array}$} & \multicolumn{2}{|c|}{ Infectivity ratio } \\
\hline & $\frac{\text { Mice infected }}{\text { Mice in group }}$ & $\begin{array}{c}\text { Percentage } \\
(y)\end{array}$ & & $\begin{array}{l}\text { Mice infected } \\
\text { Mice in group }\end{array}$ & $\begin{array}{c}\text { Percentage } \\
(y)\end{array}$ \\
\hline $4 \cdot 9$ & $25 / 60$ & 42 & $4 \cdot 3$ & $25 / 62$ & 40 \\
\hline 4.9 & $40 / 77$ & 52 & $4 \cdot 1$ & $35 / 89$ & 39 \\
\hline $4 \cdot 7$ & $33 / 68$ & 49 & $3 \cdot 8$ & $35 / 80$ & 44 \\
\hline $4 \cdot 6$ & $59 / 98$ & 60 & $3 \cdot 7$ & $42 / 61$ & 69 \\
\hline $4 \cdot 4$ & $45 / 60$ & 75 & $3 \cdot 3$ & $47 / 60$ & 78 \\
\hline $4 \cdot 0$ & $57 / 60$ & 95 & & & \\
\hline
\end{tabular}

From the above data the regression lines have been calculated for each virus pool and are as hereunder: Regression of percentage of mice infected $(y)$ on log dilution $(x)$ for pool 1 virus $Y=317-55 \cdot 6 x ;$ Regression of percentage of mice infected $(y)$ on log dilution $(x)$ for pool 2 virus $Y=216-42 \cdot 2 x$. Substituting $50 \%$ for $y$ in these equations gives ID 50 's $0 \cdot 2 \mathrm{ml} . \times$ $10^{-4 \cdot 8}$ for pool 1 virus and $0 \cdot 2 \mathrm{ml} . \times 10^{-3 \cdot 93}$ for pool 2 virus.

In a repeat experiment for each virus pool, the same assumptions and procedures were followed but the regression lines were drawn through two points based on entirely new data. About 150-200 mice were divided at random into three approximately equal groups. One group (pretreated group) was inoculated with Eperythrozöon coccoides 6 days before virus inoculation, and the other two groups (simultaneous groups) were treated with the parasite one day before they were inoculated with virus. A dose of virus, estimated as sufficient to infect about $30-50 \%$ of mice, was inoculated into the group of pre-treated mice and into one group of simultaneously-treated mice. Ten times this dose of virus was inoculated into the other group of simultaneouslytreated mice. The infectivities for the pretreated and simultaneously-treated mice in the experiment with pool 1 and pool 2 virus have already been presented in Table 1 (Expts. 2 and 4 ). The infectivity rate for the simultaneouslytreated mice inoculated with ten times the dose of virus was $65 / 69(94 \%)$ for pool 1 virus and $46 / 53(87 \%)$ for pool 2 virus. These results, expressed as percentages, are summarized below:

Pretreated mice

Simultaneously-treated mice

\begin{tabular}{|c|c|}
\hline \multicolumn{2}{|c|}{ Pool 1 virus } \\
\hline $\begin{array}{l}\text { Log virus } \\
\text { dilution }\end{array}$ & $\begin{array}{l}\% \text { mice } \\
\text { infected }\end{array}$ \\
\hline $5 \cdot 0$ & 51 \\
\hline $5 \cdot 0$ & 45 \\
\hline $4 \cdot 0$ & 94 \\
\hline
\end{tabular}

\begin{tabular}{|c|c|}
\hline \multicolumn{2}{|c|}{ Pool 2 virus } \\
\hline $\begin{array}{l}\text { Log virus } \\
\text { dilution }\end{array}$ & $\begin{array}{l}\% \text { mice } \\
\text { infected }\end{array}$ \\
\hline $4 \cdot 3$ & 57 \\
\hline $4 \cdot 3$ & 31 \\
\hline $3 \cdot 3$ & 87 \\
\hline
\end{tabular}


It will be seen that for pool 1 virus, an increase of log dilution by $1 \log$ unit lowered the infectivity from 94 to $45 \%$, that is, by $49 \%$. Pretreatment of mice with $E$. coccoides raised the infectivity from 45 to $51 \%$, i.e. $6 \%$ and this percentage increase is therefore equivalent to decreasing the log dilution by $6 / 49$ or 0.12 in simultaneously-treated mice. Similarly, for the pool 2 virus one $\log$ unit dilution lowered the infectivity from 87 to $31 \%$, i.e. $56 \%$, and pre-treatment with $E$. coccoides raised the infectivity from 31 to $57 \%$, i.e. $26 \%$. This percentage increased infectivity in pretreated mice is equivalent to decreasing the log dilution $25 / 56$ or 0.46 in simultaneously-treated mice. Thus the four independent results for the decrease in log dilution in simultaneouslytreated mice to give the same infectivity as that for pretreated mice are:

$\begin{array}{cl}\text { Pool } 1 \text { original expt. } & 0 \cdot 34(=\log 2 \cdot 2) \\ \text { Pool } 1 \text { second expt. } & 0 \cdot 12(=\log 1 \cdot 3) \\ \text { Pool } 2 \text { original expt. } & 0 \cdot 36(=\log 2 \cdot 3) \\ \text { Pool } 2 \text { second expt. } & 0 \cdot 46(=\log 2 \cdot 9) \\ \quad \text { Mean } & 0 \cdot 32(=\log 2 \cdot 1)\end{array}$

Although it might appear that the closeness to the mean of the results in the original experiments with virus of both pools resulted from the greater accuracy of the regression of infectivity on log dose in these experiments, it will be seen in fact that the wide deviations from the mean in the second experiments resulted from wide differences of infectivity between pretreated and simultaneously-treated mice in these experiments ( 6 and $26 \%$ ). Since the anti$\log$ of 0.32 is $2 \cdot 1$, it is concluded that about twice as many virus particles must be inoculated into simultaneously-treated mice as into pre-treated mice to infect an equal proportion of them and that the estimate of 'twice as many virus particles' varied in the four experiments from 1.3 to 2.9 times as many virus particles. Equivalently, we may say that if the probability of a virus particle actively infecting a liver cell of a mouse in which $E$. coccoides is not effectively present is $p_{1}$ and its probability of doing so in a mouse in which the parasite is effectively present is $p_{2}$, the ratio $p_{1} / p_{2}$, termed $\alpha$, has an estimated value of $1 / 2 \cdot 1$, i.e. about 0.5 and varied in the experiments from $1 / 2 \cdot 9$ to $1 / 1 \cdot 3$ which is from 0.34 to $\mathbf{0 . 7 7}$. Statement of the result in terms of probability relates to the probability of a virus particle producing a cell-virus union which is active and does not imply that $E$. coccoides increases the infectivity of virus by altering the virus itself. Indeed, it is more likely that the host cells are altered by infection with the parasite.

\section{Regression of survival time of virus-infected mice on the time of infecting them with Eperythrozöon coccoides}

It would be expected that the greater probability of virus particles infecting cells in the presence of Eperythrozöon coccoides would also manifest itself by the swifter spread of virus throughout the liver cells of mice in which $E$. coccoides was effectively present. Qualitatively it has been repeatedly observed that mice pretreated with $\boldsymbol{E}$. coccoides die of hepatitis following an injection of virus sooner than mice which receive the blood parasite at the same time as 
the virus. This observation can be put on a quantitative basis by making the assumptions that, following inoculation of virus, the number of virus infected cells increases logarithmically with time until such a number of cells have been infected that the mouse inevitably dies of hepatitis. With these assumptions it can be shown that the average survival time $\left(y_{1}, y_{2}, y_{3}\right.$, etc.) of groups of mice inoculated with the same dose of $E$. coccoides at times $\left(x_{1}, x_{2}, x_{3}\right.$, etc.) measured from the time of inoculation of a constant dose of virus yield points which fall on a line and that the slope of this line is $(1-\alpha)$, where $\alpha$ is, as before, the ratio of the probability $\left(p_{1}\right)$ of a virus particle infecting a liver cell in the absence of $E$. coccoides to its probability $\left(p_{2}\right)$ of doing so in the presence of $E$. coccoides. The derivation of the equation of this line is as follows.

Suppose that an inoculated dose of virus infects $N_{0}$ mouse liver cells and that after time $t$ (measured from the time of infection with virus), the number of infected liver cells is $N$. In the case of a mouse in which $E$. coccoides is effectively present at the time of infection with virus $(t=0)$, optimal virus growth will occur from the beginning and the number of infected cells $N$ at time $t$ will be given by $N=N_{0} e^{k t}$, where $k$ is a constant and $e$ is the base of natural logarithms. If $E$. coccoides is not effectively present at the commencement of virus growth and if the probability of a virus particle infecting a cell in the absence of $\boldsymbol{E}$. coccoides is $\alpha$ times the probability of its infecting a cell in the presence of this parasite, the number of cells infected at time $t$ in the absence of the parasite will be given by $\alpha N_{0} e^{\alpha k t}$. Consider a group of mice inoculated with a dose of virus at time zero and with a dose of $E$. coccoides at time $x$ and suppose that from time zero to time $t^{\prime}$ there are insufficient blood parasites present to influence virus growth and that after time $t^{\prime}$ the number of blood parasites is sufficient to give optimum virus growth. Then, the number of infected cells $N_{1}$ at time $t_{1}$ is $\alpha N_{0} e^{\alpha k t^{\prime}}$ and the number $N$ infected at time $t\left(t>t^{\prime}\right)$ is $N_{1} e^{k\left(t-t^{\prime}\right)}$, that is $\alpha N_{0} e^{\alpha k t^{\prime}+k\left(t-t^{\prime}\right)}$. Suppose that when a certain critical number of cells $\left(N_{2}\right)$ have been infected (at time $t^{\prime \prime}$ ) the mouse is predetermined to die and that death occurs, on the average, after a further time $A$. Then, $N_{2}=\alpha N_{0} e^{\alpha k t^{\prime}+k\left(t^{\prime \prime}-t^{\prime}\right)}$. If the observed average survival time for the group of mice is $y$, then $t^{\prime \prime}=y-A$. If $B$ is the average time from the inoculation of $E$. coccoides until it enhances virus growth, then $t^{\prime}=x+B$ and thus $N_{2}=\alpha N_{0} e^{\alpha k(x+B)+k(y-A-x-B)}$. Taking logarithms, rearrangement of terms gives the relationship $y=\left[\frac{1}{k} \log \frac{N_{2}}{\alpha N_{0}}+A+B(1-\alpha)\right]+(1-\alpha) x$. The first three terms of the right side (enclosed in square brackets) are constant for constant doses of virus and $E$. coccoides and may be replaced by the symbol $a$ to give the equation $y=a+(1-\alpha) x$. There are obvious limitations to the values of $x$ for which this equation may be expected to be valid. If the inoculation of $E$. coccoides follows the inoculation of virus by more than 1 day (i.e. if $x>1$ ) the virus would grow sufficiently to make many mice resistant before the parasite became effective and the equation could not be applicable (see Fig. 1). In the other direction, if $\boldsymbol{E}$. coccoides were inoculated into groups of mice more than 4 days before the virus (i.e. groups in which $x<-4$ ), the parasite would exert its full effect in all the groups from the time the virus was first inoculated: for example, three groups of mice inoculated with the parasite, 5, 6 and 7 days before virus inoculation, all would have the same minimal survival time and the equation connecting their average survival times with times of inoculation of $E$. coccoides would be a line parallel with the $x$-axis in place of the line of slope $(1-\alpha)$. The range from $x=-3$ to $x=0$ would be expected to lie well within the zone of validity of the equation $y=a+(1-\alpha) x$.

The following experiment was carried out in order to test whether the regression of survival time on time of inoculation of Eperythrozöon coccoides 
is linear, and to evaluate $\alpha$. Pool 2 virus suspension was diluted to give 80 ID 50/mouse dose $(0 \cdot 2 \mathrm{ml}$.), distributed in four bottles each containing $12 \mathrm{ml}$. and stored at $-70^{\circ}$. Two hundred and ten mice were inoculated with $10^{-3}$ dilution of spleen mince from an $E$. coccoides-infected mouse which showed no macroscopic evidence of hepatitis; the inoculated mice were then randomly divided into four groups each of 50 mice, leaving 10 mice as controls. The first group of 50 E. coccoides-treated mice were forthwith inoculated from a bottle

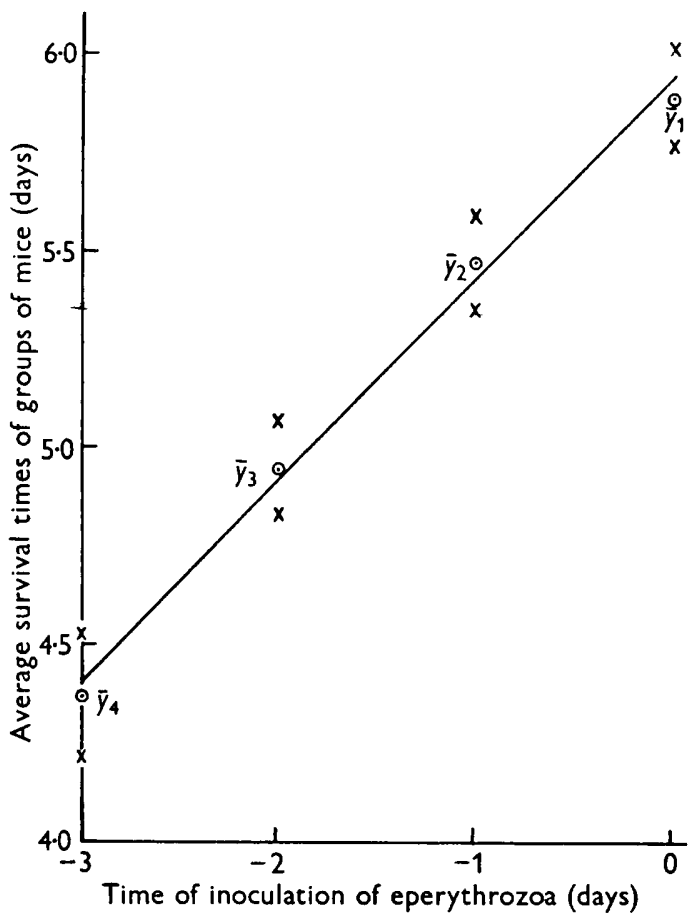

Fig. 3. Regression of mouse survival time $(y)$ on time of infection with eperythrozoa $(x)$. $\bar{y}_{1}$, mean survival time of mice inoculated with eperythrozoa at time $x=0 ; \bar{y}_{2}$, mean survival time of mice inoculated with eperythrozoa at time $x=-1 ; \bar{y}_{3}$, mean survival time of mice inoculated with eperythrozoa at time $x=-2 ; \bar{y}_{4}$, mean survival time of mice inoculated with eperythrozoa at time $x=-3$. All indicated by $\odot$. Standard errors of each mean $\left(\bar{y}_{1}, \bar{y}_{2}\right.$, etc.) indicated by $\times$. Regression line $Y=5 \cdot 94+0 \cdot 51 x$ calculated from survival times of individual mice.

of virus suspension. For this group of mice (group 1) $x$, the time of inoculation of $E$. coccoides, was zero. Exactly $24 \mathrm{hr}$. afterwards the second group of treated mice was similarly inoculated with virus suspension and for this group $x=-1$. The third and fourth groups of mice were similarly inoculated with virus suspensions 48 and $72 \mathrm{hr}$. after treatment with $E$. coccoides suspension; for these $x$ was equal to -2 and -3 respectively. The number of mice found dead of hepatitis at each $12 \mathrm{hr}$. interval after receiving virus was noted; the results are shown in Table 3 . Using the time of death of each mouse $(y)$ and the time when it was inoculated with $E$. coccoides $(x)$ (both measured from the time of virus inoculation) for determining the regression of $y$ on $x$, the following line was 
Enhancing action of eperythrozoa on mouse hepatitis 301

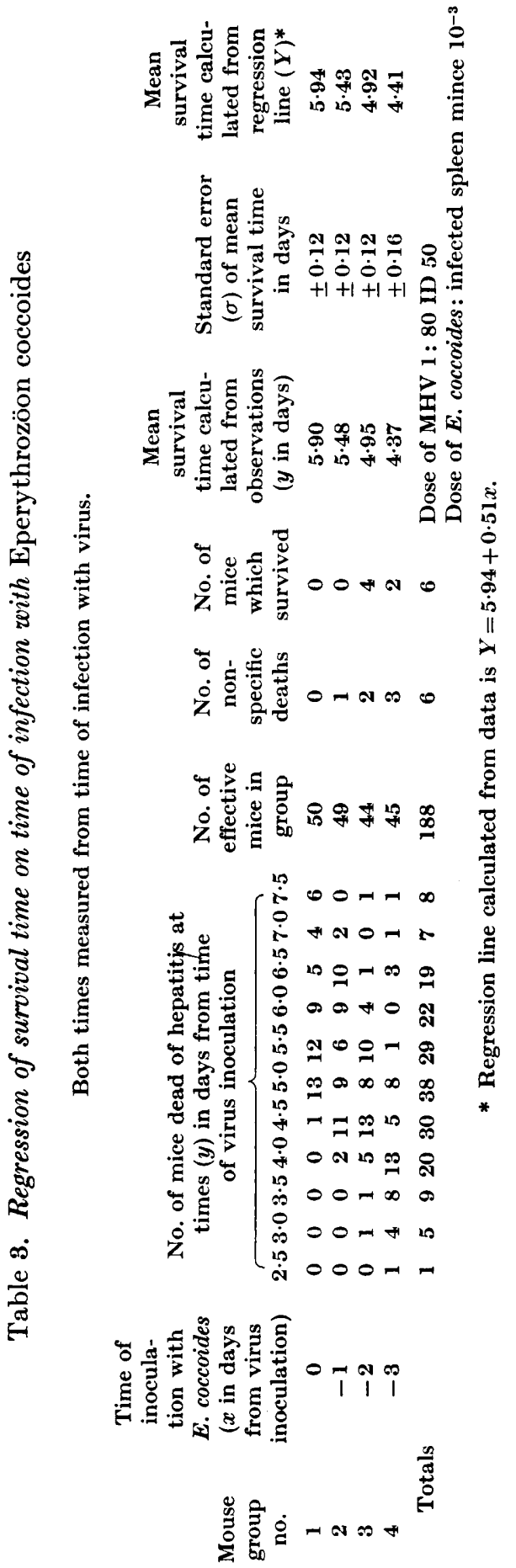


defined: $Y=5 \cdot 95+0.51 x$. This line is illustrated in Fig. 3, together with the four points representing the mean survival times $(\bar{y})$ for each group of mice (shown in Table 3). It will be seen that the points fall close to the line and, in fact, no point is further from the line than half the standard error of the determination of $\bar{y}$ for the point itself. Thus, the results are consistent with the hypothesis that the relationship between average survival time and the time of inoculation with $E$. coccoides is linear within the limits of $x$ varying from -3 to 0 . The slope of the regression line $(0.51)$ can be equated with that of the theoretical line $(1-\alpha)$ and the equation so obtained yields a value of 0.49 for $\alpha$ which, it will be recalled, is the ratio of the probability of a virus particle infecting a cell in the absence of $E$. coccoides to its probability of doing so in the presence of the parasite. Moreover, from the data presented in Table 3 the standard error of $\alpha$ (which is the standard error of the slope of the regression line) is calculated to be 0.06 giving $0.37-0.61$ as the range for 0.95 probability of including the true value of $\alpha$. It will be recalled that by the first method the mean value of $\alpha$ was estimated to be 0.5 and individual results varied within the limits of $0 \cdot 34-0 \cdot 77$.

Since the dilution of Eperythrozöon coccoides suspension was $10^{-3}$ instead of $10^{-7}$ (as more usual) it might have contained MHV 1 virus if the donor mouse had happened to be a virus carrier (Gledhill \& Dick, 1955). However, the control mice (uninoculated with virus) sacrificed 7 days after inoculation with $E$. coccoides showed no macroscopic or microscopic evidence of hepatitis. Blood smears were taken daily from these control mice. $E$. coccoides were absent from all smears 1 day after inoculation; it appeared in small numbers in two of the mice 2 days after inoculation, was present in all smears in moderate numbers 3 days after inoculation and reached maximum numbers 4 days after inoculation. As preliminary experiments had shown that $\boldsymbol{E}$. coccoides begins to enhance MHV 1 growth after the parasites are first demonstrable in blood smears but before they reach a maximum, virus growth in the fourth group of mice $(x=-3)$ was probably enhanced from the time of virus inoculation.

\section{DISCUSSION}

The first method of determining $\alpha$, the ratio of the probability of a virus particle actively infecting a liver cell in the absence of Eperythrozöon coccoides to the probability of its doing so in its presence, depended upon determination of the increased infectivity of MHV 1 virus suspension in mice pre-treated with $E$. coccoides. It might be contended that this increased infectivity was really due to a greater severity of hepatitis in pre-treated mice as a result of which some instances of hepatitis detected in them would have escaped detection if they had been simultaneously treated with $E$. coccoides. Experiments showed that the proportion of simultaneously treated mice which died of hepatitis within 14 days of infection with about one ID 50 dose of virus equals the proportion of mice which showed lesions within 7 days of infection with the same dose of virus. Moreover, mice autopsied on the 7 th day practically all showed either severe progressive hepatitis or no evidence of hepatitis. The facts 


\section{Enhancing action of eperythrozoa on mouse hepatitis}

strongly support the view that mice which develop hepatitis at all develop fatal hepatitis when $E$. coccoides is effectively present in the middle and late stages of virus growth. This excludes the view that pretreatment with E. coccoides raises the proportion of mice.with hepatitis by making observable some instances of hepatitis which would escape notice in simultaneouslytreated mice. The second method of estimating $\alpha$ clearly yielded results of greater accuracy than the first method. Thus, in the second method (using 200 mice) the range within which lies the $\mathbf{0 . 9 5}$ probability limits for the true value of $\alpha$ is from 0.37 to 0.61 as compared with a range from 0.34 to 0.77 for the four results of the first method (using about 1200 mice). Nevertheless, the first method is such that there does not appear to be any other way of interpreting the results than by supposing that $E$. coccoides increases the probability of virus particles infecting cells; whereas the result obtained by the second method can equally be interpreted by the supposition that $E$. coccoides causes every infected cell to produce about twice as many virus particles as it would have produced in the absence of the parasite. Within the framework of the hypothesis which suggested the experiments described in this paper, the increased probability that active infection forthwith results from the introduction of the virus particles in the presence of $E$. coccoides is considered to result from the parasite's causing an increase in the proportion of active infections of cells from about $50 \%$ to about $100 \%$, with a corresponding reduction of latent infections of cells from about $50 \%$ to practically none.

Natural carriers are believed to be mice in which some liver cells are infected with latent virus. Whether their latent cell infections are due to virus resembling the ordinary virus which has been used for the experiments or to a variant virus which produces a higher proportion of latent infections was not determined (Gledhill \& Dick, 1955). Since it now appears that the ordinary virus produces only $50 \%$ latent infection of cells, it is unlikely that carriers are mice infected with small doses of such virus but are probably infected with a variant of MHV 1 which produces a proportion of latent infections of cells so much higher than $50 \%$ that infection does not spread thraughout the liver in the absence of $E$. coccoides. Preliminary evidence for the existence of less virulent variants of MHV 1 virus has been obtained and infection of unweaned mice with them appears to produce weanling carriers which simulate natural carriers. In the MHV group of viruses it appears as if the virulence of strains depends upon the proportion of active cell infections which they produce and this proportion rises in a continuous series from that of the virus in carrier mice to that of ordinary MHV 1 and even to that of agents such as MHV 2 (mouse hepatitis virus described by Nelson, 1952) and MHV 3 (Dick et al. 1956) which are fully virulent in the absence of $E$. coccoides.

The author gratefully acknowledges the continued help of Dr Janet S. F. Niven, especially in connexion with experiments described herein and necessary preliminary experiments, and the useful criticism of Professor G. W. A. Dick, Dr F. B. Bang and Dr C. H. Andrewes, F.R.S. The author also wishes to thank Miss M. V. Mussett for checking the calculations and Mr A. W. Lane for technical assistance. 


\section{REFERENCES}

Dick, G. W. A., Niven, J. S. F. \& Gledhill, A. W. (1956). A virus related to that causing hepatitis in mice (MHV). Brit. J. exp. Path. 37, 90.

Gledhill, A. W. \& Andrewes, C. H. (1951). A hepatitis virus of mice. Brit. J. exp. Path. 32, 559.

GLedhill, A. W. \& Dick, G. W. A. (1955). The nature of mouse hepatitis virus infection in weanling mice. J. Path. Bact. 69, 311.

Gledhill, A. W., Drck, G. W. A. \& Andrewes, C. H. (1952). Production of hepatitis in mice by the combined action of two filterable agents. Lancet, ii, 509 .

Gledhill, A. W., Dick, G. W. A. \& Niven, J. S. F. (1955). Mouse hepatitis virus and its pathogenic action. J. Path. Bact. 69, 299.

Nelson, J. B. (1952). Acute hepatitis associated with mouse leukemia. I. Pathological features and transmission of the disease. J. exp. Med. 96, 293.

Niven, J. S. F., Dick, G. W. A., Gledhill, A. W. \& Andrewes, C. H. (1952). Further light on mouse hepatitis. Lancet, ii, 1061.

ReEd, L. J. \& Muench, H. (1938). A simple method of estimating fifty per cent end points. Amer. J. Hyg. 27, 493.

Webster, L. T. (1937). Inheritance of resistance of mice to enteric bacterial and neurotropic virus infections. J. exp. Med. 65, 261.

(Received 12 March 1956) 